\title{
Müzelerde Uygulanabilecek Müze Eğitim Etkinlikleri
}

\author{
Educational Activities Applicable in Museums
}

\section{Derya PEKGÖZLÜ KARAKUŞ*}

$\ddot{O}_{z e t:}$ Bu çalışma günümüzde üzerinde önemle durulan müze kavramı, müzecilik ve müze eğitimi ile ilgili konuları içermektedir. Çalışmamızda müze kavramının tanımı, müzeciliğin gelişimi, dünyada ve ülkemizde müze eğitiminin gelişimsel süreci incelenmekte ve asıl üzerinde durulması gereken önemli bir konu olan müze eğitiminde uygulanabilecek çeşitli etkinliklerden örnekler verilmektedir. Türkiye'de müzecilik yaklaşık yüz elli yıllık geçmişe sahiptir. Bu süre içinde müzecilikte olumlu gelişmeler yaşanmıştır. Müze kültürünün gelişmesinde, müzelerin eğitim ortamı olarak kullanılmasının önemli bir yeri vardır. Müze eğitimi; müzenin amacını ve niteliklerini, sergileri, sergilenen sanat eserlerini, müze ortamını, müze çevresini, müze ile insanlar arasındaki ilişkiyi ve müzenin disiplinler arası yönlerini ele alırken, müzenin aktif bir öğrenme ve gelişme alanı olarak kullanımını da içermektedir. Eğitim sürecinde müzelerden daha aktif ve verimli bir şekilde yararlanılabilmesi için; Kültür ve Turizm Bakanlığı, Vakıflar Genel Müdürlüğü, Milli Eğitim Bakanlığı, Yerel Yönetimler, Sivil Toplum Örgütleri ve çeşitli kuruluşların işbirliği içinde çalışmaları gerekmektedir.

Anahtar Sözcükler: Müze, Müzecilik, Müze Eğitimi, Müze Eğitim Etkinlikleri

Abstract: In this study, the concept of the museum, museology and museum education, which are emphasized today, are described; the definition of the museum concept, improvements to museology and the developmental process of museum education, both in Turkey and in the world are surveyed; and examples of the various activities applicable in museums, which is the important subject of focus, are given. Museology in Turkey has a history of approximately a hundred and fifty years. Within this period positive developments have happened in museology. Using museums as a learning environment has taken an important place in the development of museum culture. While museum education deals with the purpose and qualifications of the museum, exhibitions, exhibited art works, the museum environment, the museum area, the relationship between the museum and people, the interdisciplinary aspects of the museum, it involves using the museum as an active learning and development area. In order to more actively and efficiently benefit from museums during the educational process, the Ministry of Culture and Tourism, the General Directorate of Foundations, the Ministry of National Education, Local Administrations, Non-Governmental Organizations and various institutions must work in cooperation.

Keywords: Museum, Museology, Museum Education, Educational Museum Activities

\section{Müze Kavramı}

Uluslararası evrenselleşme ve kültürler arası arayışlar içinde olan insanoğlu, sürekli olarak değişimden etkilenmektedir. Bundan dolayı, yeni arayışlar içinde geçmiş ile geleceği buluşturma girişimindedir. Bu çabaların gösterildiği mekanlar, müzelerdir (Erbay, 2009, 11).

Müze, toplumun kültürel ve bilimsel geçmişini yansıtan ve geleceğini biçimleyecek öğeleri

\footnotetext{
* Uzman Sanat Tarihçi, Alanya Belediyesi Kültür ve Sosyal İşler Müdürlüğü, Alanya, deryapekgozlu@hotmail.com
} 
araştıran, toplayan, koruyan, sergileyen, yaşatan ve yönlendiren yaygın bir eğitim kurumudur (Kültür ve Turizm Bakanlığı 1984).

Müze kelimesinin; Hellen Mitolojisi'nde güzel sanatlar ve tiyatronun ilham perileri olan Mousa'ların annesi Mnemosyne'nin adından geldiği, Klasik Dönem'de destan, müzik, aşk şiiri, orotoryo, tarih, trajedi, komedi, dans ve gökbilimini sembolize eden yarı tanrı, dokuz Musa'nın tapınaklarına da müze denildiği (Demirtaş, 2009, 5) ve müze kelimesinin "Bilimler Tapınağl" anlamını da ifade ettiği (Erdoğan, 2003, 1) bilinmektedir. 15. yüzyılın ikinci yarısında Medici Ailesi'ne ait bir koleksiyonun tanıtılmasında "Müze" kelimesinin kullanıldığı, buna "kamu yararına" cümlesinin eklendiği, tarihsel süreç içerisinde 1962'de ICOM'un düzenlediği bir sempozyumda araştırma, koruma, eğitim ve kültür etkinliklerinin de katılmasıyla üç işlevli bir kurum niteliği taşıdığı dikkati çekmektedir (Demirtaş, 2009, 5).

Ülkelere göre müze tanımı irdelendiğinde, İngiltere Müze Birliği’ne göre müze: “Kamu yararı için maddi kanıtları ve bu kanitlarla ilişkili bilgileri toplayan, belgeleyen, muhafaza eden, sergileyen ve yorumlayan bir kurum"dur. Amerikan Müzeler Birliği’ne göre ise: "Varlığının başlıca amacı geçici sergiler düzenlemek olmayan federal ve eyalet vergilerinden muaf olan, topluma açık olup, toplum çıkarları çerçevesinde yönetilen, sanatsal, bilimsel, tarihsel ve teknolojik materyaller de dahil olmak üzere, eğitimsel ve kültürel değerlere sahip nesne ve örnekleri koruyan, muhafaza eden, inceleyip, yorumlayan, bir araya getiren toplumun ögrenmesi ve e $\breve{g}$ lenmesi için sergileyen, kar amacı gütmeyen daimi bir kurum”dur (Demir, 2001, 3-4).

Bir araştırmacıya göre, "Müzeler, sadece bir bina ve koleksiyon değildir; müze toplar, fakat bir depo değildir; müze korur, fakat bir buzluk değildir; müze belgeleri oluşturur, fakat bir kütüphane değildir; müze eğitir, fakat bir okul değildir. Müzeler üstlendikleri görevleri nedeniyle, birer açı üniversite, her hangi bir ailenin tüm fertlerinin ĕglenerek öğrenebileceği ögrenmenin bir zevk olabileceği birer kültür merkezleri” şeklinde tanımlanmaktadır.

Müzeciliğin Batılı soyluların kişisel zevkleri için çeşitli sanat eserlerini ya da kumandanların ganimetlerini bir araya toplamaları sonucu gelişmiş daha sonra diğer insanlar da bu eserleri, kendi evlerinde, tapınaklarda, kiliselerde toplamaya başlamıştır (Erdoğan, 2003, 2).

İlk müze, Hellenistik Dönem'in kültür merkezlerinden İskenderiye'de, İ.Ö. 300 yılında I. Ptolemaios zamanında yapılmıştır. Bu dönemde sanata ve bilime önem verildiğinden, bir araya gelen okullar, müzeleri meydana getirmiştir. Gerçek anlamda ilk müze, 1683 yılında İngiltere'de Oxford Üniversitesi'nde kurulmuştur ve “Ashmolean Müzesi” adını taşımaktadır. Bu müzede Elias Asyhmole'nin koleksiyonlarından faydalanılmıştır. Üniversite bünyesinde kurulan müzeler, 17. yüzyılda herkesin faydalanabileceği birer kurum haline getirilmiştir (Erdoğan, 2003, 1).

18. yüzyılda dar kapsamlı olan müzeler, 19. ve 20. yüzyıllarda klasik koruma ve sergileme anlayışıyla hizmet vermiştir (Sezgin ve Karaman, 2009, 179), 20. yüzyıl ortalarına gelindiğinde, müzecilikte kültür ve bilimin toplumun tüm kesimine aktarılması amaçlanmış ve bu şekilde geliştirilmeye çalışılan müzecilik anlayışı eğitim, toplama, koruma, inceleme, değerlendirme ve sergilemenin yanı sıra yönlendirici etkinlik olarak da biçimlenmiştir (Erdoğan, 2003, 2).

Günümüzde müzeler, toplumu aydınlatmak amacıyla insanlığın gelişimi, doğa olaylarının oluşumu ve teknolojinin geçirdiği değişim gibi konularda araştırmalar yapan, toplumların bilim ve sanat ürünleri ile yer altı ve yer üstü zenginliklerini sergileyen kurumlara dönüşmüştür (Sezgin ve Karaman, 2009, 179). Doğa bilimlerinden güzel sanatlara kadar çok geniş bir alana yayılan koleksiyonculuk çabaları, bugün artık tasnif etme, kataloglama, yerleştirme, tanıtma ve eğitici işlevlere açık, yalnız müzeciliği ilgilendiren uzmanlık düzeyindeki bilgilerden oluşmaktadır. Bu bilgiler, genellikle geçen yüzyılda hızlanan Endüstri Devrimi'nin ortaya çıkardığ 1 yeni uzmanlık alanlarıyla da ilgilidir. Diğer bir deyişle müzecilik, birtakım değerli eserleri toplamaktan oluşan geleneksel dar ölçülerden çıkarak, yeni ve çağdaş bir kavram olmuştur. 
Geleneksel müzecilik daha çok arama, toplama, koruma, bakımını yapma ve sergileme anlayışıyla sınırlıyken; çağdaş müzecilik ise, iletişim kurma ve eğitme işlevlerini de üstlenmektedir. Sonuçta etkin, dinamik, etkileşimci ve katılımcı bir müzecilik anlayışına geçilerek, kitlelerin gereksinimleri ve ilgi alanları doğrultusunda ilişki kurulmuştur (Erdoğan, 2003, 2).

ICOM, çağdaş müzeyi "toplumun ve gelişiminin hizmetinde olan, halka açık, insana ve yaşadı̆̆ çevreye dair tanıklı eden malzemelerin üzerine araştırmalar yapan, toplayan, koruyan, bilgiyi paylaşan ve sonunda inceleme, eğitim ve zevk alma doğrultusunda sergileyen, kâr düşüncesinden bağımsız sürekliliği olan bir kurumdur” şeklinde tanımlamaktadır (Demirtaş, 2009, 5).

Çağdaş müzecilik anlayışının temelinde; müzelerin kendi özel konuları içinde, olabildiğince çok eseri toplayarak, korunmasını sağlamak ve bunları halkın yararına sunmak amacı vardır. Sonuçta günümüz müzeleri tarih, sanat ve kültür yuvaları olma çabası içinde, görevlerini en iyi biçimde yerine getirmeyi hedeflemektedir (Erdoğan, 2003, 2).

\section{Tarihsel Süreçte Müzecilik Eğitimi ve Müze Eğitim Teknikleri}

Müzeciliğimizdeki dar kalıpları aşmak, çağdaş müzecilik kavramına ulaşmak, müzecilik eğitimi ile gerçekleşir. Müzelerin geleceğe dönük olarak varlıklarını devam ettirebilmesi, müzecilerin etkinliklerini arttırmasına bağlıdır. Müzecilerin en önemli ihtiyacı ise eğitimdir. Günümüzde yoğun olarak yaşanan ekonomik, teknolojik gelişim müzeciliği etkilese de ona sahip çıkmak eğitimin görevidir (Erbay, 2009, 322).

Eğitim ve öğretimde müzelerin rolü, 1857 yılında John Ruskin'in İngiltere Parlamentosu'na müzeleri; çalışan sınıfların eğitiminde kullanılmasını önermesiyle başlamıştır. Amerika Birleşik Devletleri'nde halk eğitimi için müzelerden yararlanılmaktadır. Yirminci yüzyılın başından beri müze eğitimi bir uzmanlık alanı olmuştur. Metropolitan Sanat Müzesi’nden Henry Watson Kent, değişik kesimlere ulaşmak ilkesini savunmuş; 1909 ile 1929 yılları arasında Newark Müzesi yöneticiliğini yapan John Cotton Dana ise, müzelerin; eğitimde toplumsal sorumluluğu olduğuna ve bunun öncelikli misyonu olması gerektiğine inanmıştır.

Psikolojik etkenlerin, eğitim açısından etkili bir şekilde kullanılmasını ilk kez 1905-1945 yılları arasında Arthur Parker sağlamıştır. Parker, "müzelerin mümkün olduğu kadar çok kişiye hitap edebileceğini ve gerek uzun, gerekse kısa vadeli ilgi çekici programlar hazırlayarak yerel halkn kültür düzeyini yükseltmekte kullanabileceğini” " ileri sürmüştür. Tüm yaş gruplarına hitap edilirken, çocuklara özel ilgi gösterilmelidir. Çünkü çocukların sergileri anlayabilmeleri için özel ilgiye ihtiyaçları vardır. Müzeler kapsamında gerçekleştirilen, eğitim amaçlı çoğu düzenleme ve alıştırma bilimsel yaklaşıma dayanmaktadır. Çocukların çoğu, bu tür eğitim programlarına öğretmenlerinin zoraki yönlendirmesiyle katılır ve özellikle ilgilerini çekmediği ya da gezi sonunda bir yoklama yapılmayacağını bildikleri taktirde; programa dikkat etmez, anlatılanları izlemez ve dinlemezler. Geleneksel yöntem; yani bir müzenin herhangi bir sergi salonunda çocuklara oradaki eserlere ilişkin bilgi vermek, etkili bir eğitim yöntemi değildir. Çocuklar saatler süren açıklamaları dinleyemezler ve sergilere olan ilgileri azalır. Bu nedenle çocukların dokunmaları, görmeleri ve duymaları lazımdır. Böyle bir eğitim süreci hem eğlenceli, hem faydalı, hem de hoş bir şekilde çocukların öğrenimine yardımcı olacaktır (Shabbar, 2001, 68-69).

Melbourne Müze Eğitim Servisi, gelen ziyaretçilere "yaşadıkları hayatı ve kendilerini" anlamalarına rehber olacak bir dizi program geliştirmiştir. Aynı şekilde müfredatı destekleyici materyaller hazırlamıştır (Greg, 2001, 31). Örneğin, Almanya'da oldukça önemli konuma sahip Museums Pedagogisches Zentrum çocukların ve gençlerin müzedeki eğitim merkezidir. Burada farklı eğitim çağlarındaki öğrencilere rehberli gezi, açıklama, tartışma ve atölye çalışmaları yaptırılmaktadır. Diğer bir deyişle bu merkez, aktif öğrenmeyi temel almaktadır (Yücel, 1999, 89). Tate Galerisi'nde 1976 yılında 'Körler için Heykel' adı verilen bir sergi gerçekleştirilmiştir. Bazıları koleksiyonlardan, bazıları da özel olarak tahsis edilmiş heykellerden oluşan bu sergi, 
aktif öğrenme açısından etkili olmuş ve 1980'li yıllarda açılan sergilerde, özellikle heykel alanında, dokunma döneminin başlangıcı olmuştur (Hooper-Greenhill, 1999, 160).

1984 yılında Amerikan Ulusal Sanat Eğitimcileri Topluluğu'nun bir toplantısında müze eğitimi ile ilgili olarak; görsel algıyı geliştirme, sanat ve sanat müzeleri hakkında olumlu duygular yaratma, sanatı değerlendirme, kültürel şartları öğretebilme gibi amaçlardan söz edilmektedir. Bu görüşlerin sonunda, müzelerde sanatsal mirası öğretme ve sanatsal değerlendirme yapabilmek için etkin yöntem ve tekniklerin galeri oyunları, doğaçlama, keşif ve eser karşısında tartışma gibi aktif etkinlikler olduğu konusunda anlaşmaya varılmıştır.

Bu bağlamda ülkemizde, 1997 yılında ODTÜ Geliştirme Vakfi'nca düzenlenen müze eğitimiyle ilgili bir proje mevcuttur. Bu projenin amacı, okullarda ve müzelerde, öğretmen, öğrenci ve uzman girdilerine dayanarak bir müze eğitimi programının bilişsel, duyuşsal ve psikomotor alanlardaki etkililiğini incelemektedir.

$\mathrm{Bu}$ çerçevede şu sorulara yanıt aranmıştır: Öğrencinin, bilgileri kendisinin geliştirmesi için okulda ve müzede ne yapılabilir? Öğrenme nasıl aktif hale getirilebilir? Öğrenciyi müzede meşgul etmek ve öğrencinin dikkatini toplamak için ne yapılabilir? Müze ortamı ve etkinlikleri, öğrenciye fiziksel, sosyal ve zihinsel yönden açık olarak nasıl tasarlanabilir? Müze yaşantısı ile ders programları ve okul etkinlikleri arasında öğrencilerin bireysel ve kültürel gelişimleri açısından devamlılık ve bütünlük nasıl sağlanabilir? Bu projede yapılan gözlemler ve uygulamalar sonucunda okul-öğretmen-öğrenci-müze ilişkisinin, müzelerin aktif öğrenme alanı olarak kullanılmasındaki rolünün açıkça anlaşıldığı belirtilmektedir. Kültürel ve tarihî zenginliklerin, müze eğitimi hizmetlerinin pilot projeler ve okul-müze projeleri kapsamında geliştirilmesi ve yerleştirilmesine öncelik verilmesinde yarar görüldüğü ifade edilmektedir (Şahan, 2005, http://www. tebd.gazi.edu.tr/arsiv/2005_cilt3/sayi_4/487-501.pdf).

Eğitim sürecinde müzelerden daha aktif ve verimli bir şekilde yararlanılabilmesi için; Kültür ve Turizm Bakanlığı, Vakıflar Genel Müdürlüğü, Milli Eğitim Bakanlığı, Yerel Yönetimler, Sivil Toplum Örgütleri ve çeşitli kuruluşların işbirliği içinde çalışmaları gerekmektedir.

Okullarla müzeler arasındaki ilişki, müzelerin öğretmenlere vereceği seminerler ve konferanslar sayesinde geliştirilebilir. Öğretmenler, müzelerdeki sergi konularını kendi müfredatlarına alabilir, çocukları hazırlayabilir ve coşkulu bir biçimde müzeye getirebilir. Çünkü çocuklar üzerinde öğretmenlerin etkisi daha uzun sürelidir. Müze ziyaretleriyle kendilerine verilmek istenenleri alan çocuklar, derslerini çok daha etkin bir biçimde takip etmektedir (Shabbar, 2001, 68-69). Bu nedenle, kültürel ve tarihi zenginliklerin müzelerde sergilendiği ülkemizde, Müzecilik eğitimi hizmetlerinin pilot projeler ve okul-müze projeleri bazında geliştirilmesi ve yerleştirilmesine öncelik verilmesinde yarar görülmektedir (Şahan, 2005, http://www.tebd.gazi. edu.tr/ arsiv/2005_cilt3 /sayi_4/487-501.pdf).

Okuldaki hemen hemen tüm dersler, müzelerdeki eserlerden doğru biçimde yararlanılarak daha aktif bir hale getirilebilir. Gençlerin müzeleri sık sık ziyaret etmeleri, bu gezilere çoğu zaman aileleri ve arkadaşları ile birlikte gelmeleri sayesinde; gerek bilgi gerekse kişisel zevk ve estetik bakış açısı kazandırılarak müzelere ziyaret alışkanlığı geliştirilebilir. Bu ziyaretler, okullar kapandıktan sonra da eğitim ve öğretimin durmadığı fikrinin benimsenmesi anlamına gelir ki, işte o zaman bu eğitim, "Yaşam Boyunca Ĕgitim" demektir (Rose, 1958, 8-9).

Avrupa ve Amerika müzeleri, müze görevlerinin yanı sıra eğitimi ciddi olarak üstlenmişlerdir. Buradaki müzelerin çoğunda özel dershaneler ve atölyeler bulunmaktadır. Bu atölyelerde anaokulu çocuklarına gerçeğe yakın arkeolojik objeler verilmekte, onlardan kil veya hamurla kendilerine verilen objelerin aynısını yapmaları istenmektedir. "Yaşam Boyu Eğitim" sürecinde çok yönlü öğrenme ve yaşam alanları olan müzelerin, yaşantılara dayalı etkin kullanımını içeren Müze Eğitimi, tarihsel ve kültürel zenginlikleriyle öne çıkan ülkemizde yeni ve ihtiyaç duyulan 
bir alandır (Kuruoğlu, 2002, 278).

Ülkemizde Müze Eğitim Programlarında uygulanan yöntemler arasında yaratıcı drama oldukça önemlidir. Yaratıcı drama; çocuğun zihinsel, fiziksel ve duygusal gelişimini, yaratıcı düşünme yeteneğini ve iletişim becerilerini geliştiren; sonuca değil, sürece yönelik bir çalışma alanıdır. Çocuğun kendisini tanımasını ve yapabilirliklerinin farkına varmasını sağlayan yoğun bir süreçtir. Yaratıcı dramada her oyun, çocuğu özel bir problem çözmeye odaklamaktadır (Atagök, Özkasım, \& Akmehmet, 2006, 4-5). Bu tür bir eğitim tüm müzelerde uygulanabilir.

Örneğin, Pera Müzesi’ndeki eğitim çalışmalarında; Picasso-Suite Vollard Sergisi için hazırlanan eğitim programında genç ve küçük katılımcılar, Picasso'nun gravürlerinde işlediği temaları inceleyip, yorumlayıp, atölyede baskı çalışmaları yapmıştır. Üç ana bölümden oluşan Etkinlikler Programı dört farklı yaş grubuna göre hazırlanmıştır. Program 6-7 yaş grubu ile 1518 yaş grubu arasında değişmektedir (http://www.peramuzesi.org.tr/egitim/detay.aspx?SectionID $=4 \mathrm{zJJ} 3 \% 2 \mathrm{bYsyeGUs7Q7v2XzoQ} \% 3 \mathrm{~d} \% 3 \mathrm{~d} \&$ ContentID $=$ zNrgkapLx $5 \mathrm{cc} 94 \mathrm{k} 91 \mathrm{DUpMg} \% 3 \mathrm{~d} \% 3 \mathrm{~d} \quad 10$ Şubat 2010). Seramik Atölyesi’nde, çocuklar temel seramik yöntemlerini öğrenerek kil, kalıp ve yardımcı seramik malzemelerini kullanmaktadır. Çizgi Roman Atölyesi’nde, çizgi romanın ne tür bir sanat olduğu ve tarihsel sürecinin anlatımıyla başlayan atölye çalışması, öncelikle çizimle ilgili teknik bilgileri, öykü oluşturma tekniklerini ve yazım kurallarını içermektedir. Devamında ise, çocuklar en az bir sayfalık çizgi roman oluşturmaktadır. Böyle bir program da müzelerde uygulanabilir (http://www.peramuzesi.org.tr/egitim/detay.aspx? 10 Şubat 2010).

Bodrum Sualtı Arkeoloji Müzesi'nde, Müze Eğitim Programları çerçevesinde müze hakkında bilgi veren çeşitli broşürler ve bir adet kitapçık çıkarılmıştır. Bu broşürlerin müzeyi ziyarete gelenler için eğitim aracı olduğu düşünülebilir. Ayrıca Yılanlı Kule'de yaratıcı drama çalışmaları yapılmakta; müze, tiyatro oyunlarının oynandığ 1 bir alan olarak değerlendirilmektedir. Yine ilk defa çocuklara yönelik küçük bir kitapçık hazırlanmış ve sunulmuştur.

Bunların yanı sıra, müze eğitim programları dahilinde, Müzelerin Eğitim Atölyesi Bölümünde çocuklara müzeleri ve eski eserleri sevdirmek, onlarda ilgi uyandırmak amacıyla basit küçük eser onarımları ile seramik, heykel, resim gibi konularda eğitsel çalışma olanakları sağlanabilir ve üretilen eserler sergilenebilir. Yine toplumun her kesimine eski eser ve kültürel miras bilincini aşılamak amacıyla çeşitli Eğitim-Kültür Etkinlikleri düzenlenebilir. Bu etkinlikler; konferans, uygulamalı anlatım, oyun (ilçe okullarına yönelik), sergi ve yayın şeklinde olabilir.

Efes'te olduğu gibi, bilmece şeklinde arkeolojiye yönelik çeşitli sorular sorulur ve kazananlara armağanlar verilebilir. Keza, bir antik tiyatro oyunu müzelerde sahnelenebilir (Erdoğan, 2003, 9-15). Alanya Arkeoloji Müzesi'nde uygulanan müze eğitiminde olduğu gibi, buraya gelen öğrencilerden müzedeki objelerden birini seçip canlandırma yapmaları istenebilir.

Bursa Kent Müzesi'ni ziyaret eden ilköğretim öğrencilerine gezi sonrasında çocuk bülteni verilmektedir. 4 ayda bir yayımlanan çocuk bülteninde müzenin gündeminden haberler, sanat eleştirisi soruları, bulmacalar, müzedeki objelerden birkaçının tanımları yer almaktadır. İlköğretim 1. sınıf öğrencilerine Karagöz-Hacivat kukla yapımı öğretilebilir ve bu kuklalar eğitim çalışmaları panosunda öğrencilerin isimleriyle birlikte sergilenebilir. Ayrıca Adını Sen Koy Оуипи aracılığı ile çocuklarda ilgi uyandırarak müzedeki objeleri farklı bakış açılarıyla değerlendirebilmeleri sağlanabilir, disiplinler arası çalışmayı öğretmek ve objeyle öğrenciyi yakınlaştırarak heyecan uyandırıp bağ kurmasını sağlamak amacıyla hazırlanan oyun, müzelerin çalışma sistemini öğretip müzeciliğe karşı ilgi uyandırmak hedefini taşımaktadır. Öğrencilerden ellerindeki objenin niteliklerini ölçerek, tadarak, dokunarak hangi malzemeden yapıldı̆̆ını, ölçülerinin ne olduğunu yani objenin nicel özelliklerini anlatması istenir. Daha sonra ellerindeki objeyi kimlerin kullanmış olabileceği, hangi dönemde nasıl kullanıldığı ya da ne işe yaradığı, adının ne olduğu ile ilgili fikir yürütmesi istenerek, öğrencinin objeyi tanımlaması sağlanır. Gerçeğe en yakın cevabı veren ya da en çok yorum yapabilen grup oyunu kazanır (http://www. 
bursakentmuzesi.com/egitim-calismalari, 23 Mayıs 2012).

Yukarıdaki örneklerin dışında Alanya Arkeoloji Müzesi’nde uygulanan, buraya gelen öğrencilerden müzedeki objelerden birini seçip canlandırma yapmaları istenmektedir. Bununla ilgili yapılmış proje aşağıda verilmektedir.

2008 yılında Alanya İlçe Milli Eğitim Müdürlüğü'ne bağlı Konaklı Menderes İlköğretim Okulu öğrencileri ile Müze Eğitim Projesi kapsamında yapılan çalışmaya göre; öğrenciler, Sosyal Bilgiler Öğretmenleri (Bu proje, tarafimdan Akdeniz Üniversitesi Sosyal Bilimler Enstitüsü Müzecilik Anabilim Dalı'nda Yüksek Lisans yaparken Müze Eğitimi Dersi'nde gerçekleştirilmiş bir çalışmadır) ile ders programındaki konu kapsamında Alanya Arkeoloji Müzesi'ne götürülmüştür. Müzeye gitmeden önce öğretmen tarafından öğrencilere gezilecek müze ile ilgili bilgiler verilmiştir. Gezi iki aşamadan oluşmuştur. Öncelikle müze uzmanları tarafından öğrencilere görsel anlatımlı Anadolu Uygarlıkları ile ilgili sunum yapılmış; daha sonra öğrencilere, öğretmenleri tarafından müzedeki eserler tanıtılmış ve yarım saat süre verilmiştir. Bu sürenin sonunda, öğrencilerden müzedeki eserlerden bir tanesini seçmeleri ve fotoğrafını çekmeleri istenmiştir. Müze gezisinden sonra, öğrencilere bir hafta süre verilmiştir. Öğrencilerden seçtikleri eser hakkında araştırma yapmaları ve eseri kendi dönemine göre canlandırmaları, ayrıca seçtikleri eseri kum tozu, boncuk vb. materyallerle çalışmaları istenmiştir.

\section{Okul Öğrencilerinin çalıșmalarından örnekler;}

\section{Sınıf Öğrencisi Melike Lök’ün Canlandırdığı Gözyaşı Şişelerinin Hikayesi:}

"Ey! Insanoğlu ben bir gözyaşı şişesiyim. Ben de diğer arkadaşlarım gibi Alanya Arkeoloji Müzesi'nde sergilenmekteyim. Şimdi sizlere hikayemi anlatmak istiyorum. Anneler, eşler, nişanlılar; hasret kaldıkları çocukları, eşleri, nişanlıları ölen yakınları için ağladıkları zaman gözyaşlarını bana akıtırlardı. Daha sonra da kavuştuklarında beni ağladıkları kişilere hediye ederlerdi ve hediye edilen gözyaşları değerli bir mücevher gibi saklanırdl. Aslında ben içimi dökmek isterdim; ama onlar benim içimi doldururdu. Ben, günümüzdeki insanoğlunu seviyorum; çünkü beni kazılar sonucu bulunca kırılırım diye korktuklarından toprağımı bile silmeden beni Alanya Arkeoloji Müzesi'ne getirdiler; ama iyi ki toprağımı silmemişler; çünkü ben o zamanın toprağıyla yaşamak istiyorum. Arkeologların kazıları sonucunda ortaya çıkarıldı̆̆ımda fark ettim ki, bu yeni dünya benim eski dünyama hiç benzemiyordu. Eski toprăğn kokusu gibi kokmuyordu. Benim yaşadı̆̆ım dönemde her yer yemyeşildi; ama ben çıkarılırken gördüm ki, şimdi yeşil renk sadece evlerin boyalarının rengi. Ben bu müzede mutluyum yalnı istediğim bir şey var o da müzeye gelen insanlar cam kenarından bana bir göz gezdirip gidiyorlar oysa ben bana dokunsunlar beni hissetsinler istiyorum; ama sonra korkuyorum eğer dokunurlarsa eski zamanın topră̆ı üstümden gider diye”.

\section{Sınıf Öğrencisi Rabia Arslan'ın Canlandırdığı Osmanlı Kadın Kemeri'nin Hikayesi:}

"Merhaba, ben Osmanlı kadınlarının kullandiğı kemerlerden biriyim. Şu an Alanya Arkeoloji Müzesi'nde bulunmaktayım. Eskiden Osmanlı kadınlarının giydiği süslü kıyafetlerin içinde benim de ayrı bir yerim vardı. Her dönemde olduğu gibi Osmanlı kadınları da güzelliğe ve zerafete önem verirdi ve bundan dolayı kemer olarak ben de çok gösterişli yapıllyordum. Değişik tarzda kadın kemerleri türlerim vardl. Altın, gümüş, bronz gibi. Günümüzde ise, benim yerime yapımı daha kolay, işlemeleri benim kadar ihtişamlı olmayan çok çeşitli kemerler kullanılmaktadır. Eskiden hanımımın güzelliğine güzellik katarken, şu an müzede ziyaretçileri beklemekteyim; ama ben yine de burada mutluyum çünkü kırllı çöpe atıllp tamamen yok olmaktansa müzede daima beni koruyacaklar ve her gün yeni ziyaretçiler beni görmeğe gelecek".

\section{Sınıf Öğrencisi Kübra Güven'in Canlandırdığı Pan'ın Hayatı:}

"Merhaba, ben Pan. Kırların ve çobanların tanrısıyım. Babam tanrı Hermes, annem de bir çoban 
kızı olan Nymphe'dir. Şu an Alanya Arkeoloji Müzesi'nde yaşıyorum. Bu müzeye gelmeden önceki hayat hikayemi anlatmak istiyorum. Babam Hermes'in, çocuklarl arasında en ilginç efsaneye sahip olan bendim. Babamın anlattıklarına göre; annem çoban kızıymış ve onunla evlenebilmek için annemin yaşadiğ yerde çobanlık yapmış, dedemin ve annemin gönlünü almış, daha sonra, evlenmeye karar vermişler; ama ben dünyaya geldiğimde keçi ayağım ve kuyrugum, ayrıca alnımda iki boynuzum, çenemde de bir teke sakalım varmış. Ben Friglerin doğa tanrısıydım. Ormanlarda, kayalarda ve mağaralarda yaşardım. Ben hem iyi, hem de kötü bir keçiydim. Sürüleri gözetmekten, perileri seyretmekten, flütün ahenkli sesleri ile çobanları şaşırtmaktan büyük zevk alırdım. Bazen de dağlarda tek başına kalanları korkuturdum.

Daha önceleri keçi kafalı ve boynuzluydum; ama daha sonra keçi kafamdan sadece boynuzum ve sakallarım kald, ne kadar alıkoysam da insan yüzüne benzeyemedim. Bunlardan başka sizlere kötü biten bir aşk hikayemden bahsetmek istiyorum. Bir gün çok güzel bir ormanda bir orman perisiyle karşılaştım. Bu perinin adl, Syrinks'di. Ona ilk görüş̧te aşılk olmuştum ve kendime hakim olamadım ona aşkımı ilan ettim. Syrinks ise, kendisini tanrıça Artemis'e adamıştı. Çünkü Artemis ve büyük rahiplere bakire olacağına ant içmişti, o nedenle benden kaçıyordu. Bu olayı kardeşleri görmüs ve su perilerinden yardım istemişlerdi. Bir gün ben aşkımı kovalarken, tam onu pınarın kenarında yakalayı sarlmak isterken su perileri onu saza çevirdiler. Benim kollarım bir demet saza sarıldl. Bu olay üzerine büyük bir of çektim. Bunun üzerine her yeri hüzünlü ve tatlı bir melodi kapladı. Sonra anladım ki bu ses sazlardan çıkmışt. Bari bu şekilde benim ol dedim. Sonra değişik boylarda yedi saz kestim bunlar balmumuyla yan yana yapıştırarak Syrinks adını verdiğim müzik aletini icat ettim".

\section{Sınıf Öğrencisi Emine Kaçmaz’ın Canlandırdığı Herakles'in Hayatı:}

“Merhaba ben Herakles. Ben de Alanya Arkeoloji Müzesi'nde sergilenmekteyim. Gücün simgesi sayllan yarı tanrlyım. Yarl tanr olmamin nedeni babam Zeus'un ölümsüz tanrı, annem Alkmene'nin ölümlü olmasıdır. Gelin size hayatımı anlatayım; Doğduğumda beni sevenler de oldu, sevmeyenler de. Bunlardan birisi babamın karısı yani ciciannem olan tanrıça Hera'ydl. O beni hiç sevmedi. Sonradan ögrendiğime göre; beşiğimin yanına beni öldürsünler diye iki tane yllan koymuş ve ben de ikisini ellerimle boğarak öldürmüşüm ve gücümden, soğukkanlıllğımdan herkes şaşırmış. Gençliğim ise serüvenlerle geçti. Daha sonra evlendim, çocuklarım oldu. Bir çılgınlık nöbeti sırasında eşimi ve çocuklarımı öldürdüm. Bunun için tanrılar beni yargıladılar ve on iki zor işi başarmamı istediler ve sonunda bu işlerin hepsini başardım. Sonra tekrar evlendim. Çapkınlık yaptığım için, yeni karım bana zehirli sıvıya batırılmış bir elbise giydirdi. Acılar içinde kıvranıyordum. Bu acılardan kurtulmak için kendimi ateşe attım. Sevgili babam Zeus, beni Olimpos'a tanrılar arasına kattı ve ölümsüzleştirdi.

Gün boyu bir sürü turist müzeyi geziyor. Eserleri inceliyor ve gidiyor. Benim ne düşündüğ̈̈mü ne hissettiğimi anlamıyorlar. Insanlar, müzeye karşı ilgisizler müzeye gelecekleri yerde pikniklere, denize ya da çay bahçelerine gidiyorlar. Ben onların yerinde olsaydım, okumadık kitap, gezmedik müze bırakmazdım. Ayrıca o müzeleri sadece gezmekle kalmaz o eserlerin bir bir hangi döneme ait olduğunu, müzeye ne zaman getirildiklerini öğrenirdim".

\section{Sonuç}

Günümüzde müze eğitimi, okullar için rehberli turlar düzenleme anlamını çoktan aşıp, sergileri, atölye çalışmalarını, yayınları da içeren, sadece öğrencileri değil, aileleri yani yetişkinleri de içine alan çok daha geniş etkinlikler bütünü olarak algılanmaktadır. Bugün müze eğitimi, farklı yaş gruplarından geniş kitleleri farklı etkinlikler aracılığıyla müzeye çekmeyi, müzeyi insana sevdirmeyi planlarken, bu planların gerçekleștirileceği özgür bir öğrenme ve hareket alanı yaratılmasının gerekliliğini de gözler önüne sermektedir (Karadeniz, 2009, 459). 
Milli Eğitim Bakanlığı Talim ve Terbiye Kurulu, müzelerle eğitim ve öğretimi bütünleştirme çabalarını sürdürmeye devam etmektedir. Bu çabalar doğrultusunda kurulun, müze eğitimi sürecinde rol alacak kişilerin bir uzmanlık eğitiminden geçirilmelerini sağlamak amaciyla hizmet içi eğitim etkinlikleri düzenlemek, müze eğitim sürecinde Vakıflar Genel Müdürlüğü ve Kültür ve Turizm Bakanlığı ile ortaklaşa çalışmalar yapmak, müze yönetimleri ile okul yönetimleri arasındaki koordinasyon eksikliğini gidermek, müze eğitim etkinliklerinde pilot okul uygulaması başlatmak, ders kitaplarında müzelere ilgiyi arttıracak görsel öğelere, tarihi değer taşıyan bilgi ve belgelere yer vermek, müzelerden doğrudan yararlanma imkanı olmayan okulları tespit ederek, bu okullarda okuyan öğrencilerin Türkiye müzeleri ya da ören yerleri ile ilgili sanal ortamda bilgi edinmelerini sağlamak, müzeler haftasında okullarda etkinlikler düzenlenmesini sağlamak gibi hedefleri bulunmaktadır. Milli Eğitim Bakanlığ olarak öğretmen yetiştiren fakültelerin programlarında müze pedagojisi, müze ile eğitim ve müzede eğitim alanlarında dersler verilmesini de sağlamıştır (Karadeniz, 2009, 472-473).

\section{KAYNAKÇA}

Atagök, T., Özkasım H., \& Akmehmet T. K. (2006). Okul-Müze Günleri Öğretmen Paketi. İstanbul: Yıldız Teknik Üniversitesi Basım-Yayın Merkezi.

Bursa Kent Müzesi. (23 Mayıs 2012). Yaşayan Kentin Yaşayan Müzesi, http://www.bursakentmuzesi.com/ egitim-calismalari'ndan erişilmiştir.

Demir, C. (2001). Müzelerde Çağdaş Pazarlama. İstanbul: Türkiye Anıt Çevre Turizm Değerlerini Koruma Vakfi. İstanbul.

Demirtaş, K. (2009). Müzelerde Kentsel Kültür Tarihinin Sergilenmesinde Antalya Örneği. Çukurova Üniversitesi Arkeoloji Anabilim Dalı, Yayınlanmamış Yüksek Lisans Tezi, Adana

Erdoğan, T. (2003). Türkiye'deki Arkeoloji Müzelerinde yapılan Eğitsel Faaliyetler. Ankara Üniversitesi Sosyal Bilimler Enstitüsü Müze Eğitimi Anabilim Dalı, Yayınlanmamış Tezsiz Yüksek Lisans, Ankara.

Erbay, F. (2009). Müze Yönetimini Kurumsallaştırma Çabası (1984-2009). İstanbul: Mimarlık Vakfı Enstitüsü.

Greg, H. (2001). "Museums, Means and Ends". Ethos 9, 31-32.

Hooper-Greenhill, E. (1999). Müze ve Galeri Eğitimi. Çev. Meltem Ö. Evren ve Emine G. Kapçı, Yay. Haz. Bekir ONUR, A.Ü. Çocuk Kültürü Araştırma ve Uygulama Merkezi Yayınları, s.160. Ankara.

Karadeniz C. (2009). Dünya Çocuk Müzeleri Bilim, Teknoloji ve Keşif Merkezlerinin İncelenmesi ve Türkiye İ̧̧in Bir Çocuk Müzesi Modeli Oluşturulması. Ankara Üniversitesi, Sosyal Bilimler Enstitüsü Müze Eğitimi Anabilim Dalı, Yayınlanmamış Yüksek Lisans Tezi, Ankara.

Kuruoğlu, N. (2002). "Müzelerin Eğitim Ortamı Olarak Kullanımı." Bursa: Uludağ Üniversitesi Eğitim Fakültesi Dergisi, 15, 275-285. Bursa.

Kültür ve Turizm Bakanllğı. (1984). Ankara: Eski Eserler ve Müzeler İç Hizmetler Yönetmeliği, s.1.

Pera Müzesi Eğitim Etkinlikleri. (10 Şubat 2010). http://www.peramuzesi.org.tr/egitim/detay.aspx? SectionID=4zJJ3\%2bYsyeGUs7Q7v2XzoQ\%3d\%3d\&ContentID=zNrgkapLx5cc94k91DUpMg\%3d $\% 3 \mathrm{~d}$ 'den erişilmiştir.

Pera Müzesi Eğitim Etkinlikleri. (24 Ocak 2010). http://www.peramuzesi.org.tr/egitim/detay.aspx?Section $\mathrm{ID}=\mathrm{DYN} 5 Y 7 \mathrm{Ea} 19 \mathrm{FhHb} 2 \mathrm{cI} 4 \mathrm{IrbA} \% 3 \mathrm{~d} \% 3 \mathrm{~d} \&$ ContentID=\%2bZqcB6\%2b5YdTPM9YnbLSNsw\%3d\%3d)

Rose, T. H. (1958). Müzeler ve Öğretmen, 7-13. Maarif Basımevi. Ankara.

Sezgin, M., \& Karaman, A. (2009). Müze Yönetimi ve Pazarlaması. İstanbul: Çizgi Kitapevi.

Shabbar, N. (2001 ). "Çocuklar İçin Müze Eğitimi, Kent, Toplum, Müze Deneyimler-Katkllar”. 68-74. İstanbul: Tarih Vakfi.

Şahan, M. (2005). Müze ve Eğitim. http://www.tebd.gazi.edu.tr/arsiv/2005_cilt3/sayi_4/487-501.pdf, Erişim Tarihi: 13.01.2012

Yücel, E. (1999). Türkiye’de Müzecilik. İstanbul: Arkeoloji ve Sanat Yayınları. 